\title{
Fate of herpes simplex virus in lymphocytes from inflammatory joint effusions. II. Mechanisms of non-permissiveness
}

\author{
D. J. A. APPLEFORD AND A. M. DENMAN \\ From the Division of Immunological Medicine, Clinical Research Centre, Watford Road, Harrow, Middlese \\ HAI $3 U J$
}

SUMMARY Mononuclear cells which were isolated from rheumatoid synovial effusions and culturee without prior separation failed to support the growth of herpes simplex virus (HSV). However, sul populations of $\mathrm{T}$ lymphocytes separated on the basis of cell size or receptors for sheep red cells werg, in isolation, permissive for this virus. Virus growth in these permissive cells was blocked by coculti=vation with the remaining mononuclear cell populations.

A companion paper describes experiments in which mononuclear cells isolated from rheumatoid synovial effusions failed to support the growth of herpes simplex virus type 1 (HSV) (Appleford and Denman, 1979). A number of possible explanations for this finding were excluded such as the blocking of virus receptors on lymphocytes or the lack of appropriately activated lymphocytes able to replicate HSV. In this paper we describe the results of further experiments which indicate that rheumatoid synovial effusions contain lymphocytes which, in isolation, can support the growth of HSV but lose this ability when cultured in combination with the remaining mononuclear cell populations.

\section{Materials and methods}

CLINICAL MATERIAL

Blood samples and synovial effusions from the knee joints were obtained from patients with inflammatory arthritis, as previously described (Appleford and Denman, 1979).

\section{IMMUNOLOGICAL METHODS}

Isolation of mononuclear cells. After treating the joint fluids with hyaluronidase, mononuclear cells from both joint fluids and blood were isolated by density gradient sedimentation on Ficoll/Triosil (Boyum, 1968), as described in the previous paper (Appleford and Denman, 1979).

Cell separation methods. Separation by cell size was carried out by a modification (Denman and

Accepted for publication 11 October 1978

Correspondence to Dr Denman.
Pelton, 1973) of the unit gravity sedimentation technique (Miller and Phillips, 1968). The conditions of separation by this method were standardised. fn each experiment a constant volume of $1 / 3$ to $2 \%$ Ficoll gradient was used to sediment cells for period of $2 \frac{1}{2}$ hours at room temperature. At the end of the sedimentation period $25 \mathrm{ml}$ fractions wege collected.

Macrophages were isolated by adherence to glass or plastic surfaces (Mosier, 1967). T lymphocytes were separated by rosette formation with neur minidase-treated sheep red blood cells (SRBC) (Weiner et al., 1973) followed by density sedimentation on Ficoll/Triosil (Hersey et al., 1976).

Mitogen stimulation. Suspensions of mononuclear cells at $10^{6}$ cells $/ \mathrm{ml}$ were stimulated with phytehaemagglutinin (PHA, Wellcome purified grad\&) at $0.8 \mu \mathrm{g} / 10^{6}$ cells. Stimulation was assessed oy ${ }^{14} \mathrm{C}$-thymidine uptake over an 18 -hour period 48 hours after stimulation (Janossy and Greaves, 1978.

Coulter counting and cell sizing. Coulter counter model ZB1, standardised for counting huma mononuclear cells was used. A P64 size analysier with $\mathrm{X}-\mathrm{Y}$ print-out attachment gave plots of sige distribution on a scale standardised by analysis of pollen grains in the mononuclear cell size range. -

Differential counts. These were performed $\%$ cytocentrifuge preparations stained with Ma亦Grünwald-Giesma.

Cell viability. This was measured by $0 \cdot 1 \%$ trypan blue exclusion.

Lymphocyte subpopulations. B cells with surfage immunoglobulin were identified by direct immun 2 fluorescence using a fluorescein-labelled sheep 
antibody to total human immunoglobulin (Hoechst Ltd.). $\mathrm{T}$ lymphocytes were assayed by rosetting with neuraminidase-treated sheep red blood cells (Weiner et al., 1973). Macrophages were identified by phagocytosis of yeast particles using phase contrast microscopy, and by acridine orange staining.

\section{VIROLOGICAL METHODS}

Methods for the preparation of virus stocks, infection of mononuclear cells, and measurement of virus titres were the same as those detailed in the accompanying paper (Appleford and Denman, 1979.)

\section{Results}

\section{SEPARATION OF EFFUSION LYMPHOCYTES}

\section{BY SIZE DIFFERENCE}

Mononuclear cells isolated from the synovial effusion and blood of patients with rheumatoid arthritis were separated by velocity sedimentation at $1 \mathrm{~g}$. The cell fractions were amalgamated into 3 pools termed 'small', 'medium', and 'large' on the basis of their sedimentation rate and hence their cell volume. A comparison of the sedimentation profiles of nucleated cells from blood and effusions of the same donors (Fig. 1, Table 1) showed that effusions often contained a distinctive peak of cells in the large cell range, which was not present in peripheral blood. The sedimentation profiles of blood lymphocytes obtained from patients with rheumatoid arthritis and from normal donors were identical.

Characterisation of the cells isolated in each cell pool indicated that the 'large' pool contained cells in the lymphoblast size range as well as macrophages; in addition, the 'large' pool from the effusion contained those granulocytes not removed

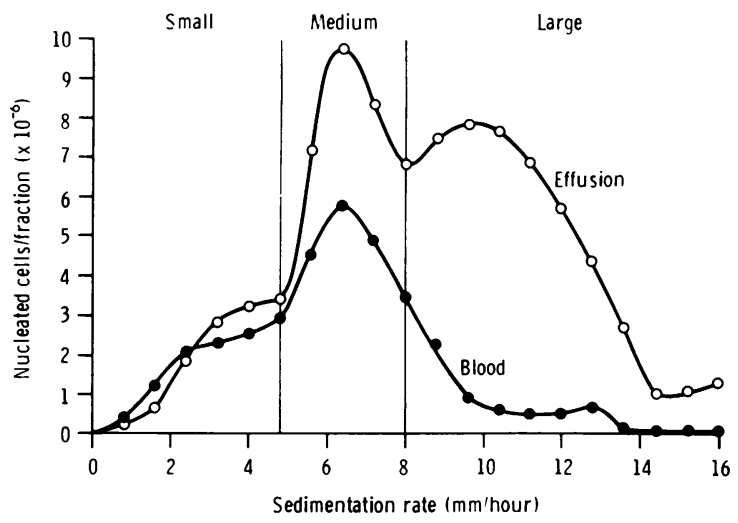

Fig. 1 Unit gravity sedimentation of blood and effusion lymphocytes from a patient with rheumatoid arthritis. Cells were sedimented on a 1/3-2\% Ficoll gradient for $2 \frac{1}{2}$ hours, after which $25 \mathrm{ml}$ fractions were collected and analysed.

by Ficoll/Triosil purification. The 'small' cell pool from both effusion and blood was relatively enriched for T lymphocytes, whereas the 'large' pool from the same source were relatively depleted of such lymphocytes.

All pools of blood lymphocytes supported the growth of HSV although large cells were less efficient in this respect (Figs. 2 and 3). However, the fate of HSV was different in lymphocyte populations of comparable size separated from synovial effusions.

Two patterns of results were obtained. In 4 patients none of the lymphocyte pools supported viral growth. In contrast, both small and medium sized lymphocytes from the synovial effusions of 2 patients

Table 1 Characterisation of mononuclear cell pools from blood and synovial effusions of patients with rheumatoid arthritis separated by velocity sedimentation

\begin{tabular}{|c|c|c|c|c|c|c|c|c|}
\hline Cell pool 1 & & $\begin{array}{l}\text { Sedimentation } \\
\text { rate }(\mathrm{mm} / \mathrm{h})\end{array}$ & $\begin{array}{l}\text { Size range } \\
\left(\mu m^{3}\right)\end{array}$ & $\begin{array}{l}\% \text { Of cells } \\
\text { recovered }\end{array}$ & $\begin{array}{l}\% \\
\text { Lymphocytes }\end{array}$ & $\begin{array}{l}\% \\
\text { Macrophages }\end{array}$ & $\begin{array}{l}\% S m I g \\
+v e\end{array}$ & $\begin{array}{l}\% E \\
\text { Rosette + ve }\end{array}$ \\
\hline Large & $\begin{array}{l}\text { Effusion } \\
\text { Blood }\end{array}$ & $7 \cdot 18-16 \cdot 0$ & $642 \cdot 0-2143 \cdot 0$ & $\begin{array}{l}44 \cdot 16^{3} \\
(28 \cdot 2-57 \cdot 8) \\
30 \cdot 65 \\
(20 \cdot 6-45 \cdot 1)\end{array}$ & $\begin{array}{l}23 \cdot 84 \\
(4 \cdot 0-34 \cdot 0) \\
82 \cdot 25 \\
(77 \cdot 0-85 \cdot 0)\end{array}$ & $\begin{array}{l}11 \cdot 7 \\
(2 \cdot 0-32 \cdot 0) \\
4 \cdot 97 \\
(2 \cdot 0-8 \cdot 9)\end{array}$ & $\begin{array}{l}5 \cdot 7 \\
(3 \cdot 4-9 \cdot 0) \\
3 \cdot 42\end{array}$ & $\begin{array}{l}17 \cdot 7 \\
(9 \cdot 0-24 \cdot 1) \\
33 \cdot 0^{2}\end{array}$ \\
\hline Medium & $\begin{array}{l}\text { Effusion } \\
\text { Blood }\end{array}$ & $5 \cdot 0-7 \cdot 18$ & $374 \cdot 0-642 \cdot 0$ & $\begin{array}{l}39 \cdot 78 \\
(22 \cdot 2-50 \cdot 0) \\
41 \cdot 32 \\
(25 \cdot 8-54 \cdot 6)\end{array}$ & $\begin{array}{l}47 \cdot 24 \\
(35 \cdot 0-62 \cdot 0) \\
92 \cdot 5 \\
(90 \cdot 0-100 \cdot 0)\end{array}$ & $\begin{array}{l}5 \cdot 1 \\
(2 \cdot 1-13 \cdot 3) \\
1 \cdot 01 \\
(0-4 \cdot 3)\end{array}$ & $\begin{array}{l}1 \cdot 76 \\
(1 \cdot 3-2 \cdot 0) \\
2 \cdot 32\end{array}$ & $\begin{array}{l}29 \cdot 33 \\
(21 \cdot 0-34 \cdot 0) \\
62 \cdot 4 \\
(52 \cdot 0-71 \cdot 0)\end{array}$ \\
\hline Small & $\begin{array}{l}\text { Effusion } \\
\text { Blood }\end{array}$ & $3 \cdot 3-5 \cdot 0$ & $200 \cdot 0-374 \cdot 0$ & $\begin{array}{l}16.09 \\
(9 \cdot 0-21 \cdot 79) \\
27 \cdot 85 \\
(25 \cdot 0-30 \cdot 0)\end{array}$ & $\begin{array}{l}76 \cdot 95 \\
(57 \cdot 0-91 \cdot 0) \\
98 \cdot 75 \\
(95 \cdot 1-100)\end{array}$ & $\begin{array}{l}0 \cdot 4 \\
(0-1 \cdot 2) \\
0 \cdot 25 \\
(0-1 \cdot 0)\end{array}$ & $\begin{array}{l}3 \cdot 63 \\
(0-6 \cdot 0) \\
7 \cdot 12\end{array}$ & $\begin{array}{l}64 \cdot 5 \\
(63 \cdot 0-66 \cdot 0) \\
82 \cdot 10 \\
(78 \cdot 5-87 \cdot 0)\end{array}$ \\
\hline Unseparated & $\begin{array}{l}\text { Effusion } \\
\text { Blood }\end{array}$ & - & 一 & - & $\begin{array}{l}59 \cdot 54 \\
(32 \cdot 5-87 \cdot 0) \\
92 \cdot 0 \\
(90 \cdot 0-93 \cdot 0)\end{array}$ & $\begin{array}{l}6 \cdot 0 \\
(3 \cdot 0-12 \cdot 5) \\
2 \cdot 85 \\
(2 \cdot 0-4 \cdot 0)\end{array}$ & $\begin{array}{l}8 \cdot 34 \\
(5 \cdot 0-14 \cdot 0) \\
16 \cdot 6 \\
(13 \cdot 4-21 \cdot 0)\end{array}$ & $\begin{array}{l}56 \cdot 86 \\
(32 \cdot 6-75 \cdot 0) \\
61 \cdot 45 \\
(60 \cdot 9-62 \cdot 5)\end{array}$ \\
\hline
\end{tabular}

1 Analysis of 4 blood samples and 6 synovial effusions. 2 Data from 1 observation only. 3 Figures are the mean (and range). Large, medium, and small cells collected as in Fig. 1. 


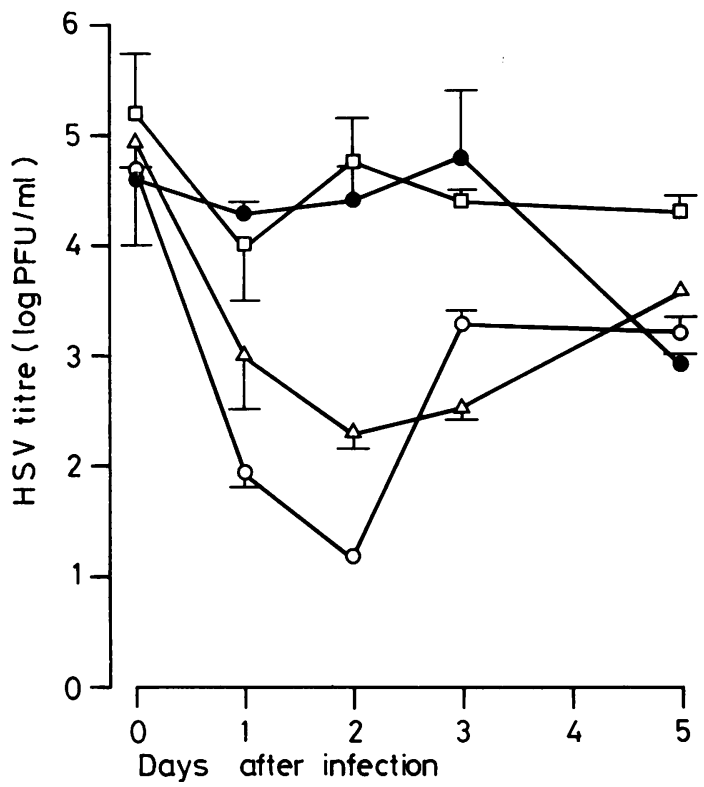

Fig. 2 Growth of HSV in blood subpopulations from a patient with rheumatoid arthritis, separated by velocity sedimentation. - -1 unseparated cells, O-O large cells, $\square-\square$ medium cells, $\Delta-\Delta$ small cells. $40 \times 10^{\circ}$ cells sedimented as described in Fig. 1 and collected in 3 pools were stimulated with $P H A$ and infected with HSV at an MOI of $0 \cdot 1$. The size range of the cells in each pool is given in Table 1.

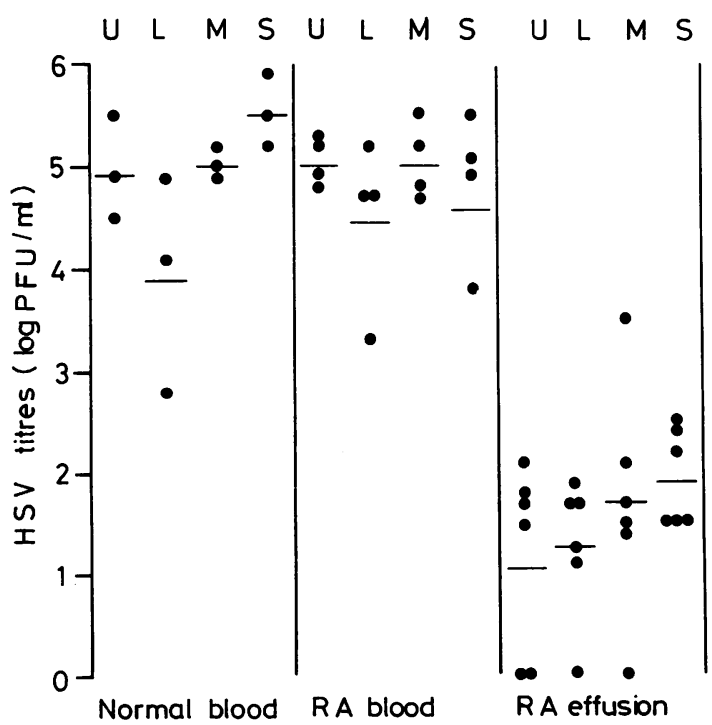

Fig. 3 Fate of $\mathrm{HSV}$ in lymphocyte subpopulations separated by velocity sedimentation. $U=$ unseparated cells; $L=$ large cells; $M=$ medium cells; $S=$ small cells. $H S V$ titres are the highest observed after 3-5 days of culture. The horizontal bar shows the mean virus titres. supported virus growth as indicated in Fig. 3 and illustrated in more detail in Fig. 4.

In addition 5 rheumatoid synovial effusions were separated by velocity sedimentation to give 4 pools of cells with a narrower range of cell size in eacter pool. All cell pools from 3 effusions failed to suppor viral growth, but virus grew to titres of $2 \cdot 5-3 \cdot 8$ logs in cells of less than $750 \mu \mathrm{m}^{3}$ isolated from the remaining 2 effusions.

\section{SEPARATION OF EFFUSION LYMPHOCYTES} BY SURFACE MARKERS

The preceding separation experiments suggeste $\frac{\vec{P}}{4}$ that synovial effusions contain cells potentiallyo able to support HSV replication. When tonsil cells or normal blood lymphocytes are exposed to HSVF this virus grows exclusively in a limited number of T lymphocytes (Pelton et al., 1977). Similarly? when blood lymphocytes from 10 patients with rheumatoid arthritis were infected with HSV only lymphocytes supported virus growth, giving titres comparable with those obtained in cultures of normaf blood T lymphocytes (Fig. 5). Since the slowlye sedimenting cells obtained by velocity sedimentatione of synovial effusions were greatly enriched for $\dot{\mathbf{B}}$ lymphocytes it seemed likely that these were the

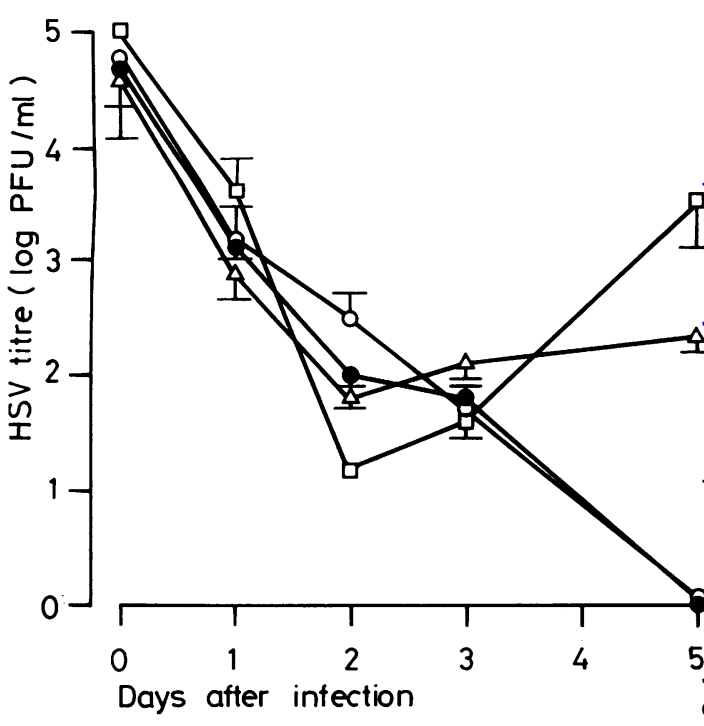

Fig. 4 Growth pattern of HSV in lymphocyte subpopulations from a rheumatoid synovial effusion. -- unseparated cells, O-O large cells, $\square-\square$ medium cells, $\Delta-\Delta$ small cells. Lymphocyte pools obtained by velocity sedimentation correspond to those illustrated in Fig. 1. Cultures were stimulated with $P H A$ and infected with $H S V$ as described in legend to Fig. 2. 
cells which supported viral growth. Indeed, $\mathbf{T}$ lymphocytes isolated from all 8 synovial effusions tested were permissive for HSV growth. The titres were comparable with those obtained in cultures of peripheral blood $\mathrm{T}$ lymphocytes from both normal donors and those with rheumatoid arthritis (Fig. 5). Details of a representative experiment are given in Fig. 6.

These results suggested that rheumatoid synovial effusions contain $\mathrm{T}$ lymphocytes able to support the growth of HSV but that this potential growth is suppressed by other mononuclear cells. To test this hypothesis $\mathrm{T}$ lymphocytes from synovial effusions were cultured in combination with other lymphocytes from the same source at varying ratios. As a control $\mathrm{T}$ lymphocytes were cultured with comparable ratios of $T$ lymphocytes that had been treated with actinomycin D to block viral growth or with non-

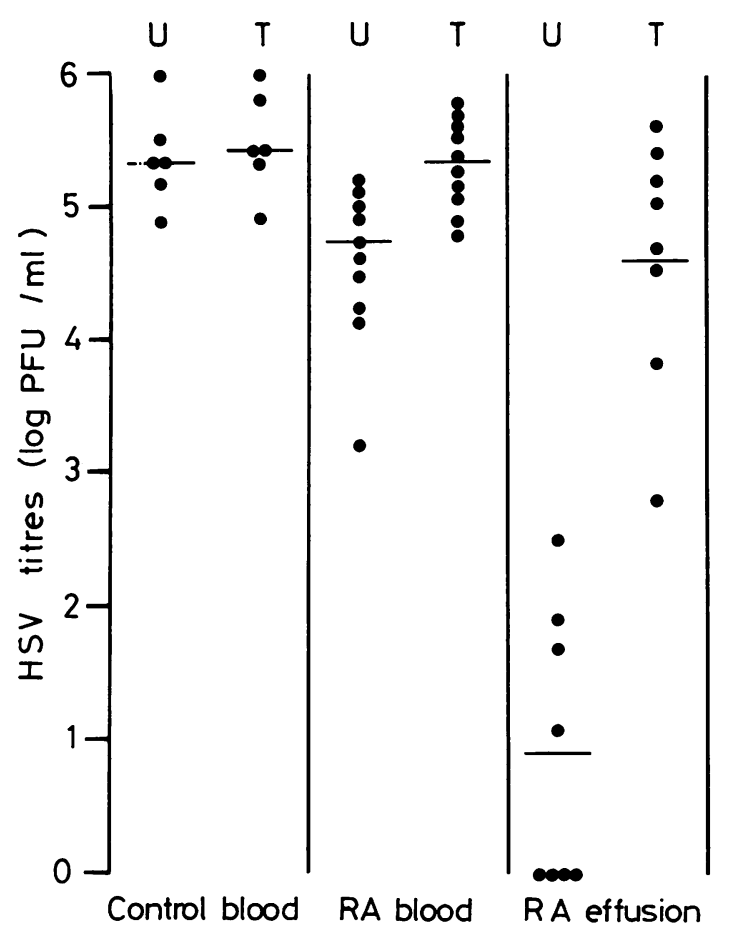

Fig. 5 Growth of HSV in T lymphocytes isolated from rheumatoid peripheral blood and synovial effusions. $U=$ unseparated cells, $T=$ lymphocytes. $T$ lymphocytes were isolated from the peripheral blood of normal controls and from the blood and effusions of patients with rheumatoid arthritis $(R A)$. Conditions of culture and $\mathrm{HSV}$ infection as in Fig. 2. Virus titres are maximal observed after 3-5 days culture. ( $T$ cells constituted $69 \cdot 02 \pm 14 \cdot 5 \%$ of the total effusion lymphocytes).

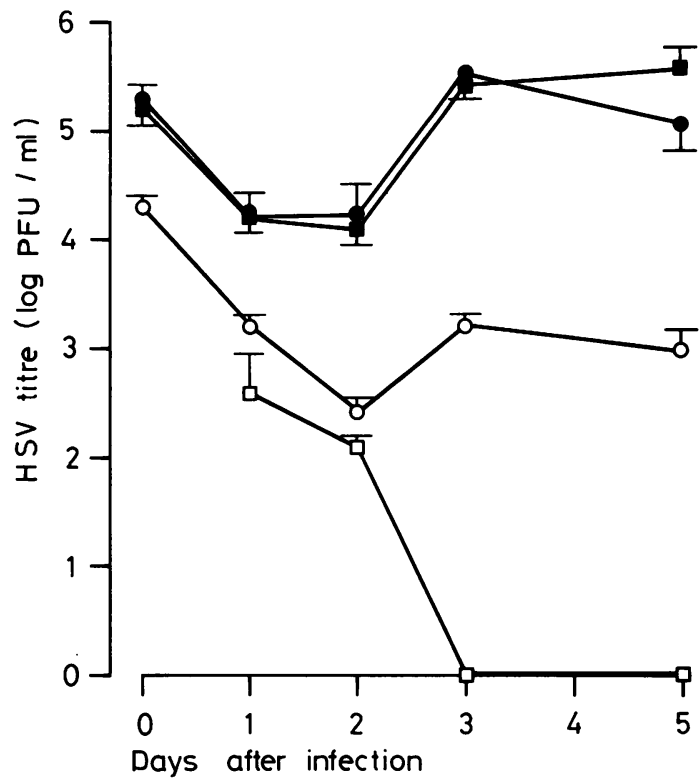

Fig. 6 Growth of HSV in T lymphocytes. - blood $T$ lymphocytes $\mathbf{\square} \mathbf{\text { effusion }} \mathrm{T}$ lymphocytes, $\mathrm{O}-\mathrm{O}$ blood unseparated cells, $\square-\square$ effusion unseparated cells. $T$ lymphocytes were isolated from the effusion infected with $H S V$ under the conditions described in Fig. 2. Figures are the mean ( $\pm I S D)$ of virus titration of triplicate cultures.

T lymphocytes from autologous blood. The results are summarised in Table 2 and illustrated in Fig. 7.

In 3 experiments $\mathrm{T}$ lymphocytes from synovial effusions cultured at a ratio of $40 \%$ untreated to $60 \%$ actinomycin-D-treated cells or $25 \%$ effusion $\mathrm{T}$ cells to $75 \%$ autologous blood non-T cells still supported viral growth. This was in keeping with our earlier observations (Appleford and Denman, 1979) in which permissive normal blood lymphocytes still supported HSV replication provided that the non-permissive cells with which the permissive cells were mixed did not constitute more than $70 \%$ of the total number. Non-T lymphocytes from synovial effusions behaved differently from other nonpermissive populations. In 5 experiments non-T effusion cells inhibited viral growth in effusion $T$ cells even when the permissive $\mathrm{T}$ lymphocytes made up more than $60 \%$ of the total number of cultured cells. In 4 out of 5 experiments synovial effusion non- $T$ cells inhibited viral growth only in $T$ lymphocytes from the same source and not in T lymphocytes isolated from the blood of the same patient. In the fifth experiment the effusion cells also prevented the growth of HSV in autologous blood T lymphocytes (Table 2). 
Table 2 Inhibition of HSV growth in T lymphocytes by other lymphocyte subpopulations

\begin{tabular}{|c|c|c|c|c|c|c|c|c|}
\hline \multirow[t]{2}{*}{ Non-T } & \multicolumn{4}{|c|}{$\%$ Effusion $T$ lymphocytes } & \multicolumn{4}{|c|}{$\%$ Blood T lymphocytes } \\
\hline & 25 & 50 & 75 & 100 & 25 & 50 & 75 & 100 \\
\hline & $\begin{array}{l}4 \cdot 5(3) \\
(2 \cdot 8-5 \cdot 4)\end{array}$ & $\begin{array}{l}3 \cdot 7(3) \\
(2 \cdot 1-4 \cdot 6)\end{array}$ & $\begin{array}{l}4 \cdot 8(3) \\
(3 \cdot 8-5 \cdot 4)\end{array}$ & $\begin{array}{l}5 \cdot 4(3) \\
(5 \cdot 2-5 \cdot 6)\end{array}$ & $\begin{array}{l}5 \cdot 1(2) \\
(4 \cdot 8-5 \cdot 4)\end{array}$ & $\begin{array}{l}4 \cdot 9(2) \\
(4 \cdot 6-5 \cdot 2)\end{array}$ & $4 \cdot 7(1)$ & $\begin{array}{l}5 \cdot 1(2) \\
(4 \cdot 8-5 \cdot 4)\end{array}$ \\
\hline
\end{tabular}

1 Non-T lymphocytes mixed with $T$ cells in concentrations to make $100 \%$. 2 Virus titre is the maximum between days 3 and 5 of culture. 3 Figures are the mean virus titre in $\log$ placue forming units (PFU)/ml (number of experiments) and (range). 4 Non-permissive effusion non-T:blood T lymphocyte mixture illustrated separately.

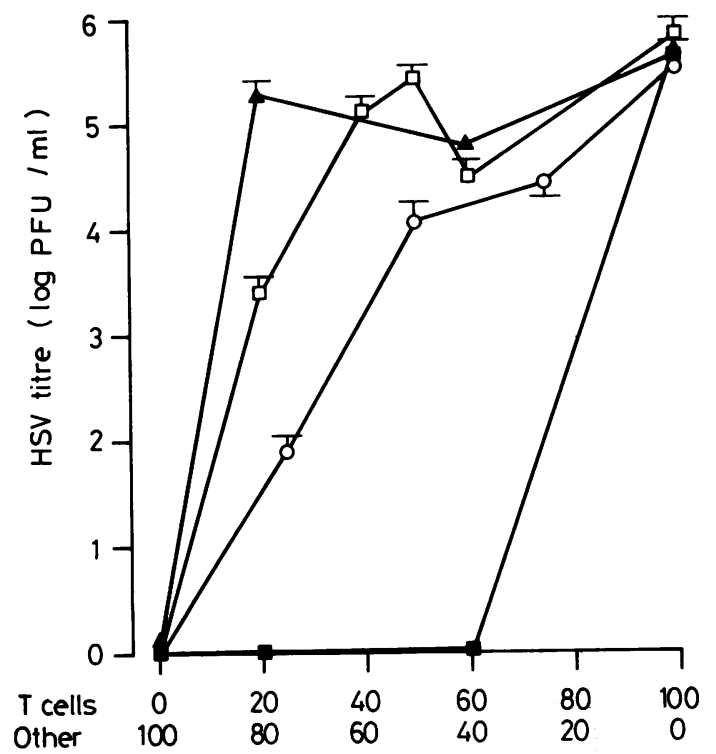

Fig. 7 Inhibition of HSV growth in T lymphocytes by other lymphocyte populations. $\Delta-\Delta$ effusion $T$ lymphocytes; blood non-T lymphocytes; $\square-\square$ effusion $T$ lymphocytes; effusion non-T lymphocytes; O-O effusion $T$ lymphocytes; actinomycin-D-treated $T$ lymphocytes; $\square-\square$ blood $T$ lymphocytes; effusion non$T$ lymphocytes. $T$ lymphocytes isolated from a rheumatoid blood and synovial effusion were cultured with varying proportions of non-T lymphocytes from the blood and effusion of the same patient. Conditions of infections in Fig. 2. Figures are mean $( \pm I S D)$.

The non-T lymphocytes responsible for blocking viral growth have not been characterised. However, in 2 experiments the inhibitory effect of effusion non- $T$ lymphocytes on effusion $T$ cells was not ablated by removal of glass-adherent cells.

\section{Discussion}

A previous paper (Appleford and Denman, 1979) reported that lymphocytes from the effusions of patients with several forms of inflammatory $y_{\infty}$ arthritis failed to support the growth of HSV ir Moreover, it was shown that this non-permissivenesser was not caused by blockade of lymphocyte virus receptors, defective lymphocyte function, or the effects of residence in the inflammatory erfusion.

Our experiments show that there is indeed an subpopulation of lymphocytes in these effusions $\bar{O}$ which in isolation supports the growth of HSV. Judged by velocity sedimentation this population consists of small and medium sized lymphocytes and was detected in 4 out of 11 effusions examined In all 4 effusions the permissive population waso enriched for $T$ lymphocytes and depleted of those cell types which constitute the majority of the large cell fractions isolated from both blood and synovia effusions. Whereas the large cell fractions isolated from blood also supported HSV replication, similaro fractions from synovial effusions were entirely non-permissive.

$\mathrm{T}$ lymphocytes isolated from synovial effusions supported the growth of HSV to titres comparable to those obtained in $T$ lymphocyte cultures from the blood of normal donors, indicating that the failure of virus to grow in effusion lymphocytes was not due to the deletion of the susceptible subpopulation Furthermore, the percentage of $T$ cells in the effusions was the same and in some cases higher than that in cultures of autologous blood lymphocytes which did support virus growth. Indeed HSV still faile to grow in small and medium cell pools from to effusions whose T-lymphocytes content exceeded $63 \%$, indicating that further purification was stiln necessary for these cells to support virus growth ${ }_{\sigma}^{\omega}$ These results suggested that the growth of HSW in $\mathbf{T}$ lymphocytes was inhibited by a subpopulation of cells separating in the non-T cell fraction. The mixing experiments in which effusion $T$ lymphocytes were diluted with varying ratios of non-T lymphocytes from the same source confirmed this conclusion $\overrightarrow{\mathbb{D}}$ It should be emphasised that similar mixtures of lymphocyte subpopulations from normal blood dif not inhibit virus growth. Further experiments 
indicated the inhibiting cells were not macrophages or $\mathrm{T}$ lymphocytes and were enriched in the rapidly sedimenting fraction, but these have not yet been further characterised.

The inhibition of virus growth could be accounted for in several ways. Some lymphocytes in the effusion might have been cytotoxic for virus-infected $T$ lymphocytes and could have killed these cells before virus replicated (Zinkernagel and Althage, 1977). As only a small percentage of human $\mathrm{T}$ lymphocytes are infected initially by HSV (Pelton et al., 1977) this killing would not result in obvious reduction in viable cell numbers. This effect is unlikely to be mediated by classical interferon, since vesicular stomatitis virus (VSV) replicated in the effusion cell cultures and infection by this virus is extremely sensitive to interferon. Moreover, interferon could not be detected in the non-permissive cultures (Appleford, unpublished observations).

Nevertheless other antiviral factors produced by lymphocytes, perhaps of a specific nature, could have been responsible (Rouse and Babiuk, 1975). It is possible that the B lymphocytes of patients with rheumatoid arthritis carry EB virus, since the sera of these patients and not normal controls contain an antibody which reacts with a characteristic nuclear antigen in B lymphocytes infected by this virus (Alspaugh et al., 1978). This infection in B lymphocytes could induce resistance in $\mathrm{T}$ lymphocytes to infection by other herpes viruses.

This would imply that the effusions contain lymphocyte populations participating in an antiviral response which can be detected by the failure of HSV to grow in T lymphocytes. There is indeed evidence for antiviral resistance of this nature. Thus human lymphocytes which normally support the growth of 17D yellow fever virus lose this permissiveness if the donor has recently been immunised against the virus (Wheelock and Edelman, 1969); the non-permissiveness does not result from direct infection of the lymphocytes.

Thus this result is consistent with the hypothesis that the cells at the site of rheumatoid inflammation are engaged in an antiviral response. Although the failure of $\mathrm{HSV}$ to replicate in T lymphocytes from synovial effusions is unlikely to reflect interference by defective virus in these cells, the possibility remains that other lymphocyte subpopulations harbour a persistent infection.

The authors thank Drs B. M. Ansell, J. M. Gumpel, and D. S. Smith for their assistance in obtaining clinical material.

\section{References}

Alspaugh, M. H., Jensen, F. C., Rabin, H., and Tan, E. M. (1978). Lymphocytes transformed by Epstein-Barr virus. Induction of nuclear antigen reactive with antibody in rheumatoid arthritis. Journal of Experimental Medicine, 147, 1018-1027.

Appleford, D. J. A., and Denman, A. M. (1979). Fate of herpes simplex virus in lymphocytes from inflammatory joint effusions. I. Failure of the virus to grow in cultured lymphocytes. Annals of the Rheumatic Diseases, 38, 443449.

Boyum, A. (1968). Separation of leukocytes from blood. Scandinavian Journal of Clinical and Laboratory Investigation, 21, suppl. 97, 1.

Denman, A. M., and Pelton, B. K. (1973). Cell separation by size. Methodological Developments in Biochemistry, vol. 2, p. 185. Edited by E. Reid. Longman: London.

Hersey, P., Edwards, A., and Edwards, J. (1976). Characterization of mononuclear effector cells in human blood. Clinical and Experimental Immunology, 23, 104-113.

Janossy, G., and Greaves, M. F. (1971). Lymphocyte activation. I. Response of $\mathrm{T}$ and $\mathrm{B}$ lymphocytes to phytomitogens. Clinical and Experimental Immunology, 9, 483498.

Miller, R. G., and Phillips, R. A. (1968). Separation of cells by velocity sedimentation. Journal of Cell Physiology, 73, 191-202.

Mosier, D. E. (1967). A requirement for two cell types for antibody formation in vitro. Science, 158, 1573.

Pelton, B. K., Imrie, R. C., and Denman, A. M. (1977). Susceptibility of human lymphocyte subpopulations to infection by herpes simplex virus. Immunology, 32, 803810.

Rouse, B. T., and Babiuk, L. A. (1975). Host defence mechanisms against infectious bovine rhinotracheitis virus. II. Inhibition of viral plaque formation by immune peripheral blood lymphocytes. Cellular Immunology, 17, 43-56.

Weiner, M. S., Bianco, C., and Nusenzweig, V. (1973). Enhanced binding of neuraminidase treated sheep red blood cells to human T lymphocytes. Blood, 42, 939-946.

Wheelock, E. F., and Edelman, R. (1969). Specific role of each leukocyte type of viral infection. III. 17D yellow fever virus replication and interferon production in homologous leucocyte cultures treated with P.H.A. Journal of Immunology, 103, 429-436.

Zinkernagel, R. M., and Althage, A. (1977). Antiviral protection by virus immune cytotoxic $\mathbf{T}$ cells, infected target cells are lysed before infectious progeny is assembled. Journal of Experimental Medicine, 145, 644-651. 